\title{
4. Private participation in the education of Syrian refugees: understanding the roles of businesses and foundations ${ }^{1}$
}

\section{Zeena Zakharia and Francine Menashy}

\section{INTRODUCTION}

Of the 57 million children worldwide without access to education, over one third live in settings of conflict and fragility (UNESCO, 2015). The escalating crisis in Syria has contributed significantly to this out-of-school population, with well over half of 1.4 million Syrian refugee children and adolescents not in school (UNICEF, 2015). The international development community has moved to respond to this and other humanitarian crises, where education in emergencies has risen as a policy priority in the mandates of international organizations (Menashy and Dryden-Peterson, 2015). However, the share of total overseas development assistance to education has declined sharply in recent years, with funding persistently low in conflict-affected states (UNESCO, 2015, 2016). Within this context, private-sector engagement in education has become increasingly appealing to a growing portion of the international community. And private actors have responded in turn.

For instance, in January 2016, during the annual meeting of the World Economic Forum in Davos, members of the Global Business

1 We are grateful to Education International who funded the study on which this chapter is based: Menashy, F. and Z. Zakharia (2017) Investing in the Crisis: Private Participation in the Education of Syrian Refugees. Brussels: Education International. The full report is available at: http://download.ei-ie.org/Docs/ WebDepot/EI_Research_Syria_final.pdf. 
Coalition for Education (GBC-E) pledged $\$ 75$ million to support the education of Syrian refugees in Lebanon, Jordan, and Turkey (WEF, 2016). Concurrently, a US State Department Forum at Stanford University in California called on the private sector to address the crisis via education. Later, in May 2016, the World Humanitarian Summit echoed this call to action (WHS, 2016). In September that same year, at the US White House Summit on Refugees, President Barack Obama presented a challenge for "the US private sector to draw on its unique expertise, resources and entrepreneurial spirit to help refugees regain control over their lives and integrate into their new communities." Education was the first of three "impact areas" Obama cited, and he detailed his aim to address this through a private sector response (White House, 2016). A range of high-profile businesses and corporate philanthropies were involved in these various initiatives, such as Goldman Sachs, Hewlett Packard, Google, LinkedIn, Microsoft, Pearson Education, Discovery Learning Alliance, IKEA Foundation, Bridge International Academies, and Rand. Numerous new private funding commitments and partnership arrangements have since been initiated to advance the cause of educating Syrian children. Such commitments are indicative of the growing role of private entities as both educational funders and providers in contexts of crisis.

Our research explores the complex interrelationship between conflict and private sector participation through a case study of the education of Syrian refugees. Although private engagement in this context is evidently expanding, the exact nature and scale of this involvement has been unclear. Conducted in mid-2016 to early2017, our study sought to better understand: (a) which private entities are engaging in Syrian refugee education in Jordan, Lebanon, and Turkey; (b) the activities through which private companies and foundations support education; and (c) the rationales and motivations that drive their involvement. Our findings derive from a range of data sources, including a systematic Internet search to determine non-state actors participating in the sector; analyses of documents, webpages, and social media from private companies and foundations; and key informant interviews with private sector actors and those who partner with them, including businesses, foundations, United Nations agencies, civil society or nongovernmental organizations (CSOs/NGOs), and bilateral donor agencies. Preliminary findings were presented to international educational 
practitioners in November 2016, with feedback contributing to our analyses and conclusions. Although we collected initial data on the full non-state sector, the analysis was restricted to private businesses and their corporate foundations. Thus, when we make reference to "private actors" or to the "private sector" in this chapter, we are referring to the activities of for-profit businesses, in particular their corporate social responsibility (CSR) programs, and their affiliated corporate foundations. CSR programs are generally funded through a corporation's general operating budget, and operate as a branch of the company to implement projects in social sectors. Whereas, corporate foundations, also known as corporate philanthropies, are generally positioned as separate from their associated company. They may share the name of their associated company (e.g., MasterCard Foundation, Hewlett Foundation, Ikea Foundation) or its leadership (e.g., Bill and Melinda Gates Foundation). Although considered nonprofit entities, corporate foundations are established using the profits of corporate endeavors.

\section{CONTEXTUALIZING THE ROLES OF BUSINESSES IN SITUATIONS OF FRAGILITY}

On the surface, the participation of the private sector in refugee education appears commendable. It is a positive development that so many high-profile actors are voicing their concern for refugee education, resulting in greater visibility of the crisis. Furthermore, supporters of private engagement in education in contexts of crisis and fragility have strong rationales for their involvement; they cite low government capacities and a lack of public funds to adequately provide education and absorb refugee populations. The private sector, they argue, can ostensibly fill this gap.

Businesses cite the notion of "shared value" as an impetus. This involves "creating economic value in a way that also creates value for society by addressing its needs and challenges" (Porter and Kramer, 2011: 4). From this perspective, humanitarian and profitbased aims can be both compatible and desirable.

Critics, however, argue that the involvement of the private sector can weaken public systems of education. It also undermines a key component of education as a human right, which is the responsibility of the state. Furthermore, in contexts of fragility-which can 
include settings of conflict or post-conflict, natural disaster, disease epidemic, or economic collapse-privatization can be seen as exploitation. Canadian journalist Naomi Klein coined the term "disaster capitalism" to refer to instances where catastrophic events are seen as an occasion to enact market-based, neoliberal reforms, or as she puts it: "the treatment of disasters as exciting market opportunities" (Klein, 2007: 6).

In education, disaster capitalism has been observed by critics in a range of contexts. In post-hurricane Katrina New Orleans, reformers overhauled the public education system to expand privately-run charter schools, citing the hurricane as a "silver lining" and an opportunity to reform a struggling public school system via market strategies (Saltman, 2007: 138). In Haiti, following the earthquake in 2010, an already highly privatized education system was supported by the Inter-American Development Bank, which partnered with the Haitian Ministry of Education to substantively subsidize existing private schools in order to strengthen the private sector (Verger, Fontdevila and Zancajo, 2016). Furthermore, in Liberia, a highly fragile context, enduring economic collapse, conflict, and most recently the Ebola outbreak, the public school system is on course to be outsourced to a for-profit company (Global Initiative for Economic, Social and Cultural Rights, 2016). In such cases, crisis hit, and actors saw an opportunity to enact policies and programs, which while addressing educational needs, concurrently promoted private-sector interests.

Of course, not all business actors exploit crises, but in the context of the Syrian refugee crisis, where we observed a very rapid rise in the involvement of corporate actors in education, we felt it necessary to look closer at their engagement.

\section{RESEARCH CONTEXT}

Statistics on access to education for Syrian refugees are staggering. Pre-war, 94 percent of Syrian children were enrolled in primary and lower secondary education. However, in August 2016, regional enrollment figures for Syrian refugee children in formal and non-formal education were estimated at 52 percent of registered school-age children (aged 5-17) in Jordan, Lebanon, Turkey, Iraq, and Egypt (UNHCR, 2016a). The gross enrollment ratios vary 
greatly among host countries with, for example, an estimated 40 percent enrolled in Turkey, 55 percent in Lebanon, and 82 percent in Jordan (see Table 4.1) (UNHCR, 2016a). Regionally, it is estimated that 739,000 registered Syrian refugee school-age children and adolescents are not enrolled in any type of educational program (UNHCR, 2016a). These figures do not account for refugees who are not formally registered by UNHCR. Thus, they should be viewed as severe underestimations. Furthermore, those who are considered "enrolled" participate in a range of educational activities, in terms of quality and type, including accelerated learning programs, literacy and numeracy-focused programs, vocational and skill-based programs, activity-based programs, and psychosocial support programs.

The three countries in our sample-Jordan, Lebanon, and Turkey-face exceptional challenges in attempting to absorb large Syrian refugee school-aged populations (HRW, 2016; OSF, 2016; UNHCR, 2016b). The three countries have dramatically shifted their recent education policies in response to the surging number of refugees. This includes double-shift schools to accommodate Syrian children and opening temporary education centers. However in all three countries, public schools face overcrowding and in most cases they are not able to absorb all of the Syrian children and youth seeking enrollment. As a result, tensions have risen within many host communities around educational issues. In light of these challenges, the role of the private sector has become increasingly salient.

Table 4.1 Gross enrollment ratios of registered school-age Syrian refugees (aged 5-17) in formal and nonformal education by host country (August 2016)

\begin{tabular}{lcc}
\hline Host country & $\begin{array}{c}\text { Gross Enrollment } \\
\text { Ratio }\end{array}$ & $\begin{array}{c}\text { Number of Registered Syrian } \\
\text { school-aged children }\end{array}$ \\
\hline Jordan & $82 \%$ & 232,470 \\
Lebanon & $55 \%$ & 379,299 \\
Turkey & $40 \%$ & 845,365 \\
\hline
\end{tabular}

Note: These figures do not account for refugees who are not formally registered by UNHCR. Thus, they should be considered underestimations.

Source: UNHCR (2016a). 


\section{NON-STATE PARTICIPATION IN THE EDUCATION OF SYRIAN REFUGEES}

Based on the data collected in the second half of 2016 alone, we identified 144 total non-state organizations engaged in Syrian refugee education in Lebanon, Jordan, and Turkey. This figure accounts for various types of for-profit and nonprofit actors, including those that might be categorized as nonprofit, non-religiously affiliated NGOs or CSOs (e.g., Arche Nova/Germany, Concern Worldwide, PARCIC/Japan, Save the Children); religiously affiliated organizations (e.g., Al-Makassed Philanthropic Association, Catholic Relief Services, FinnChurch Aid); research institutes (e.g., American University of Beirut, Carnegie Endowment for International Peace); businesses (e.g., Cisco International, Hewlett Packard, McKinsey and Company, Pearson); and private foundations (e.g., Bill and Melinda Gates Foundation, Chobani/Tent Foundation, Ikea Foundation) (see Figure 4.1). Of this total, 32 percent were businesses and an additional 10 percent were foundations, many of which are very well-known, multinational companies and philanthropies. Of these, 77 percent were headquartered in the global North, in high-income countries, and 62 percent did not hold education as part of their mandate.

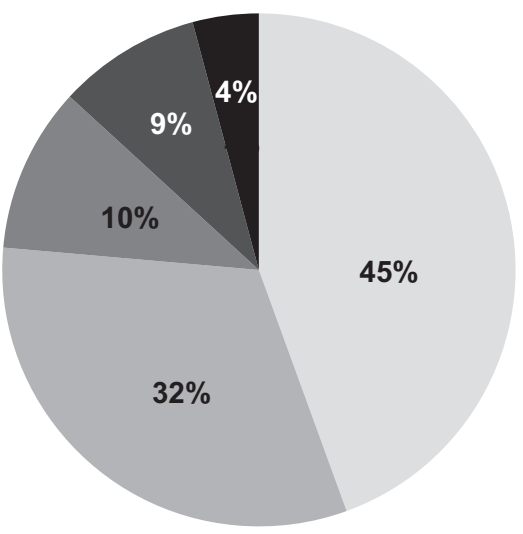

CSO Business $\square$ Foundation $\square$ Religious Org. $\quad$ Research Institute

Figure 4.1 Non-state participation in the education of Syrian refugees 
Private corporate actors, including businesses and their foundations, were engaged in a range of educational operations (see Figure 4.2), with many stating that they contributed to multiple aspects of education. The most common types of engagement were: (a) funding to the education sector, whereby 49 percent of the businesses and foundations we identified contributed funds to NGOs or UN agencies to do educational work; and (b) the development and distribution of technological education innovations, whereby another 49 percent also contributed to some aspect of educational technologies. Other common stated areas of engagement included professional development (33 percent), school construction (31 percent), and providing school supplies (31 percent). Only a few of the identified private actors were engaged in the areas of socio-emotional support (1 percent), early childhood education (3 percent), and extracurricular activities (5 percent).

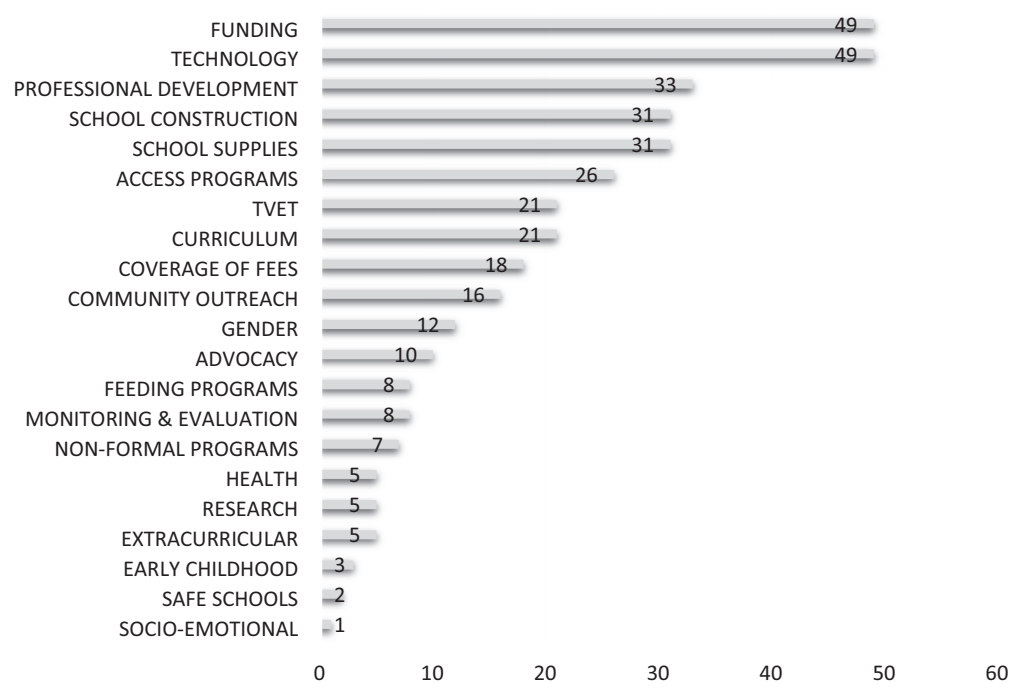

Figure 4.2 Types of educational engagement (\% of businesses and foundations) 


\section{EMERGING ISSUES}

In analyzing these data, along with our interviews, some major issues emerged as areas for concern. We group these into three sections pertaining to: (a) the mass proliferation of involvement, characterized by limited coordination of efforts; (b) the dominance of technological interventions; and (c) support for private schooling. We briefly introduce each of these issue areas below.

\section{Mass Proliferation, Limited Coordination}

The surge in private participation in the education of Syrian refugees is very recent, with most actors first engaging since 2015. This was described to us as a mass proliferation of private involvement: "From things like consulting companies, to small start-ups, to large multi-nationals, everyone seems to be involved" (Interview, Business, July 2016).

This rapid rise in involvement has been problematic according to several of our interview respondents, as there is a lack of coordination and knowledge-sharing between actors. This concern was captured by one NGO representative who stated: "It's a little crazy to be honest ... In the Syria response there are so many people doing so many things and it's not coordinated. Sometimes I really wonder if because of this lack of coordination, if this is actually doing a disservice to the sector" (Interview, NGO, July 2016).

\section{Dominance of Technology}

We also found that a dominant form of engagement is through education-related technology. We found a wide variety of technologies being introduced, such as: online digital learning platforms, online courses, tablet and handset distribution which includes online curriculum or educational games, the development of new operating systems, and portable WiFi hubs for use in schools. Some actors viewed technology as an excellent intervention because of the need for a "solution that can reach as many people as possible for the cost that is as low as possible, that involves as little teachers as possible. Because we do see that there's a huge lack of teachers" (Interview, Foundation, September 2016). 
However, many of our respondents were very critical of this over-emphasis on technology. They saw it as de-contextualized from the local context. One NGO actor captured these collective concerns in stating: "There's a disconnect between what is technically and logistically appropriate and what looks good from a branding and marketing perspective ... I think there's a lot of good intention, but a lack of awareness about what the practicalities of operating in these environments are" (Interview, NGO, July 2016). Furthermore, the overemphasis on technology is viewed as pedagogically problematic. As a representative from an NGO that supplies a technological service to refugees explained, technology can never replace a teacher (Interview, NGO, November 2016). In short, the disproportionate stress on technology may be problematic, in particular when viewed as a panacea to break down barriers to schooling for refugees.

\section{Support for Private/Non-Formal Schooling}

Many business actors work collaboratively with governments and ministries of education. However, others do not; they are bypassing the public sector and establishing privately-run schools, or what are often termed "non-formal" education environments. Separate from the public schooling system, these schools are financed via the private sector and often managed by local actors.

Business actors justify the support to privately-provided schooling, for instance saying:

You have a situation where the public sector could only absorb a fraction of those children ... Yes, the public sector wants to be in control, which is absolutely to be appreciated and respected. But it will take its natural course of expansion. And in that natural course of expansion, we need to give the kids an opportunity to pursue an accredited education outside of the public sector. (Interview, Business, July 2016)

This view that "we can't wait for the public system to catch up" is critiqued by many actors working in the region, in particular where controversial providers bypass the state and plan for pilot schools going to scale. Given that there is an assumption that the public sector cannot absorb the refugee population, the Syrian refugee context appears to be fertile ground for the establishment of 
business-supported private schooling. These include free and low fee-charging school models, for profit and not-for-profit, including charter-style arrangements with Ministries of Education. Although most initiatives are at early stages, these private school models are widely viewed as problematic, with critics arguing they foster a lack of accountability and often hire non-unionized and poorlytrained teachers. Furthermore, business-supported private schools are critiqued as having no exit strategy, potentially leaving students stranded when profits and other forms of returns no longer add up and schools close. We discuss some of these returns among the motives for private sector engagement in the following sections.

\section{MOTIVATIONS}

In addition to understanding the roles of businesses and foundations in the education of Syrian refugees, this study examined the stated motivations of private actors in getting engaged in this crisis. The following sections summarize some of the key humanitarianoriented and profit-oriented motivations.

\section{Humanitarian-Oriented Motives}

We found that some business actors have very clear humanitarianrelated motivations. Many corporate actors told us that seeing the images in the media of the scale of the crisis made them want to simply "do the right thing" (Interview, Business, July 2016), and help out. As one respondent stated: "I think there's the obvious pulling at the heart strings of CEOs" (Interview, Business, June 2016). As well, some have personal connections to the crisis, with family or loved ones in the region.

\section{Profit-Oriented Motives}

We also found that many private actors have clear profit-oriented motivations for getting involved. As one representative from a business explained, "Companies want to be affiliated with good causes, or they see some sort of strategic alignment between what their brand means and what the cause is about" (Interview, Business, June 2016). The idea of "creating markets" for business 
products is another salient motivation that emerged in a number of interviews. The Middle East is considered a big and largely untapped market for products: "In the Middle East there are a lot of diverse types of markets and this is also something that is in the interest of a private organization purview" (Interview, NGO, July 2016). As well, a context of crisis may be considered an apt setting to test new innovations: "When they're innovating new things, sometimes an area in conflict might be the right environment to test out a product or service" (Interview, Business, June 2016). Employee engagement was also cited as a motivation for getting involved, because connecting to a good cause is considered good for employee productivity and morale.

According to representatives from organizations that partner with the private sector, including UN agencies and NGOs, these profit motivations are problematic. Respondents expressed resistance to, or skepticism about, partnering with private actors who hold profit motivations in the Syrian refugee crisis: "Some of the private technology companies that we engage with are working on profit models, and so there has been some skepticism around partnership and engagement" (Interview, UN agency, July 2016). In particular, respondents found the need to develop a "business case" for investing in the crisis troubling. Respondents explained: "It can be a lucrative opportunity for smart business people" (Interview, UN agency, 2016) and reminded us that businesses are "driven by making money. I think we have to accept that" (Interview, Business, 2016).

\section{DISCUSSION}

Our study found several corporate actors-both businesses and philanthropic foundations-making notable strides in supporting the education of Syrian refugees. Private sector contributions include awareness campaigns, teacher professional development, food programs in schools, gender equity programs, vocational training, classroom materials and supplies, and innovative technological interventions such as digital libraries and curricular supports. Many businesses are fiscally supporting local and international NGOs in carrying out these efforts. Given declines in aid to education, the need for non-traditional funding sources is urgent, 
where contexts of humanitarian crisis have historically been underserved by established aid efforts.

Our research participants, however, described several interrelated areas for concern. Insufficient coordination amongst private actors participating in the sector is evident and agreed upon by many respondents to be a major weakness in endeavoring to support refugees, leading to disorganized efforts and duplication. Insufficient coordination with public-sector actors in some cases has also led to problematic engagement, skirting the host government's role in coordination mechanisms.

The absence of coordination is likely rooted in several factors. The combination of a humanitarian-driven impetus alongside a form of bandwagoning onto this issue, which is deemed timely and thus able to engender high visibility and elevate brand image, may have led to a rush in involvement without careful consideration of coordination with others, and also of context.

Furthermore, because businesses have in some cases entered this arena with longer-term profit-oriented aims, the form of intervention they introduce is often directly aligned with their company's goals - there must be a "business case" made for participation. In such cases, businesses are limited in what they contribute or promote; for instance some may defer to introducing technological interventions that can increase their brand recognition and help to widen a market for their products, but at the same time may be decontextualized from the needs of refugees. The overemphasis on technology engenders duplication of interventions and is potentially problematic from a pedagogical standpoint.

The public pronouncements made by particular actors touting the potential benefits of private schooling in conflict-affected contexts are also cause for concern, given that there is an accepted view that public sector schools in the region are unable to absorb the growing refugee populations. Support to schools provided outside the public sector could have wider implications for equity, quality, and a rights-based approach, which considers the government as the main duty-bearer for education.

A final concern rests on certain private actors' profit-oriented goals, sometimes framed alongside a claim to humanitarian goals. Yet profit-driven motivations, in our view, are in tension with humanitarian aims, where to profit fiscally from a humanitarian crisis is arguably exploitative. Some businesses have transparently 
entered this fragile context in order to create markets, increase brand recognition, engender positive public relations, envisioning it as an environment to test out new innovations, increase employee satisfaction, and thereby increase profits. When a business case is made to support the education of refugee children, a crisis is framed as an "exciting market opportunity," or what Klein (2007) would describe as disaster capitalism.

Although humanitarian-oriented motivations are clear in many cases of private participation in the education of Syrian refugees, certain businesses are focused mainly on the "bottom line" (Interview, NGO, July 2016; Interview, Business, June 2016). The very concept of "shared value," where profit-maximization can concurrently address social challenges (Porter and Kramer, 2011), arguably holds inherent contradictions. Critics of shared-value beliefs and business participation in social causes have proposed that:

[c]orporations might tend to invest more resources in promoting the impression that complex problems have been transformed into win-win situations for all affected parties, while in reality problems of systemic injustice have not been solved and the poverty of marginalized stakeholders might even have increased because of the engagement of the corporation. (Crane et al., 2014: 137)

While this research shows that the private sector has a role to play in addressing the education of Syrian refugees, it also prompts educational actors to question the ethics of making a "business case" for involvement and "investing in the crisis" (Interview, Business, June 2016).

\section{CONCLUSION}

This study seeks to offer a nuanced understanding of a complex issue: the multifaceted roles of private actors and their involvement in education in contexts of humanitarian crisis-an arena that has historically been framed as a public sector responsibility. Our findings show that businesses and foundations have a potentially important role to play in supporting the education of Syrian refugees. In the context of diminishing development aid to education, in conjunction with the enormous obstacles facing refugees 
and their already stretched host governments, the expertise and resources of the private sector are crucial.

However, our study also sheds light on areas for concern and limitations to the assumed capacity of the private sector to understand and work within rapidly evolving humanitarian contexts. To date, the private sector response has been characterized by insufficient coordination. Decontextualized interventions, in particular relating to educational technology, indicate a rush to involvement and limited understanding of context. This is particularly problematic where teachers and other local educational actors have not been consulted. Statements in the media by private actors have advocated for a push towards non-state schooling, which while presented as a way of alleviating the burden on public systems, can have implications for equity and quality. Private actors have taken on vocal, high-profile roles as policy actors and direct contributors to global humanitarian funding. According to one high-level UN official, "the UN ends up in an accommodating position" as agencies are pressured to work with the private sector, particularly those with celebrity status (personal communication, August 2017). Through this dynamic, the private sector is able to directly influence policy, spurring questions concerning a genuine commitment to provide unrestricted funds and the accountability of unelected corporate policy-makers.

As several respondents made clear, it is critical to understand the motivations of private actors in fragile contexts: while some have articulated humanitarian aims, others view support to education in settings of conflict and fragility through a bottom-line lens, where solidifying a market hold, increasing visibility and brand loyalty are central motivations, alongside those that are humanitarian-oriented. Thus, our research brings to light ethical tensions between humanitarian and profit motivations.

However, given the scale of the Syrian refugee crisis, our study also suggests that a reliance solely on traditional public-sector engagement in education is limiting and unrealistic. By exposing particular concerns, our study spurs the global education community to ask how to harness the expertise and funds of the private sector in a coordinated and ethical way that is mindful of the state's responsibility to be the primary duty-bearer to provide and regulate 
quality education. This is particularly urgent in establishing a foundation for longer-term systemic change in the service of all children.

\section{REFERENCES}

Crane, A., Palazzo, G., Spence, L., and Matten, D. (2014). Contesting the value of "creating shared value." California Management Review, 56(2), 130-153.

Global Initiative for Economic, Social and Cultural Rights. (2016). Education privatisation in Liberia. Retrieved May 21, 2018 from http://globalinitiativeescr.org/advocacy/privatization-in-education-research-initiative/educationprivatisation-in-liberia/.

Human Rights Watch (HRW). (2016). "We're afraid for their future": Barriers to education for Syrian refugee children in Jordan. Retrieved May 21, 2018 from https:/www.hrw.org/report/2016/08/16/were-afraid-their-future/barrierseducation-syrian-refugee-children-jordan.

Klein, N. (2007). The Shock Doctrine: The Rise of Disaster Capitalism. New York: Metropolitan Books.

Menashy, F. and Dryden-Peterson, S. (2015) The Global Partnership for Education's evolving support to fragile and conflict-affected states. The International Journal of Educational Development, 44, 82-94.

OSF. (2016). On the brink of a lost generation. Retrieved May 21, 2018 from http://aciktoplumvakfi.org.tr/pdf/On_the_Brink_of_a\%20Lost_ Generation.pdf.

Porter, M. and Kramer, M. (2011). Creating shared value: How to reinvent capitalism - and unleash a wave of innovation and growth. Harvard Business Review, January-February, 2-17.

Saltman, K. (2007). Capitalizing on Disaster: Taking and Breaking Public Schools. New York: Paradigm Publishers.

UNESCO. (2015). Humanitarian aid for education: Why it matters and why more is needed. Policy Paper 21. Paris: UNESCO.

UNESCO. (2016). Aid to education has gone down. Retrieved May 21, 2018 from https://gemreportunesco.wordpress.com/2016/04/25/aid-to-educationhas-again-gone-down/.

UNHCR. (2016a). 3RP Regional Refugee and Resilience Plan 2017-2018 in response to the Syria crisis: Regional strategic overview. Retrieved May 21, 2018 from http://data.unhcr.org/syrianrefugees/regional.php.

UNHCR. (2016b). Missing Out: Refugee Education in Crisis. New York: UNHCR.

UNICEF. (2015) Access to Education for Syrian Refugee Children and Youth in Jordan Host Communities. New York: UNICEF.

Verger, A., Fontdevila, C. and Zancajo, A. (2016). The Privatization of Education: A Political Economy of Global Education Reform. New York: Teachers College Press. 
WEF. (2016). A new plan to help Syria's child refugees. Retrieved May 21, 2018 from http://www.weforum.org/agenda/2016/01/hope-for-syria-s-childrefugees.

White House. (2016). White House launches a call to action for private sector engagement on the global refugee crisis. Retrieved May 21, 2018 from https://www.whitehouse.gov/the-press-office/2016/06/30/fact-sheet-whitehouse-launches-call-action-private-sector-engagement.

WHS. (2016). Connecting business: Special session. Retrieved May 21, 2018 from http://whsturkey.org/Contents/Upload/SS\%2012\%20Connecting\%20 Businesses_isuem45t.rjt.pdf. 